\title{
The Transformation of Gender Identity for Women and Men in a University Classroom
}

\author{
Jerome Rabow ${ }^{1,2}$, Gabrielle Serano ${ }^{3}$, Sara Yazdanfar ${ }^{4}$ \\ ${ }^{1}$ University of California, Los Angeles, USA \\ ${ }^{2}$ California State University, Northridge, USA \\ ${ }^{3}$ Sociology Major, California State University, Northridge, USA \\ ${ }^{4}$ Sociology Major, University of California, Los Angeles, USA \\ Email: jrabow@soc.ucla.edu
}

How to cite this paper: Rabow, J., Serano, G., \& Yazdanfar, S. (2017). The Transformation of Gender Identity for Women and Men in a University Classroom. Sociology Mind, 7, 72-79.

https://doi.org/10.4236/sm.2017.72006

Received: December 3, 2016

Accepted: April 25, 2017

Published: April 28, 2017

Copyright (C) 2017 by authors and Scientific Research Publishing Inc. This work is licensed under the Creative Commons Attribution International License (CC BY 4.0).

http://creativecommons.org/licenses/by/4.0/

\section{Open Access}

\begin{abstract}
This research paper examines the way in which a university classroom focuses upon patriarchy and sexism and the responses to these issues. The 110 students in this upper division class were encouraged to examine their beliefs and values in an environment where they could be challenged by readings, other students' reactions and web posts. These web posts were anonymous so that students could feel safe and were classified in a six-stage identity scheme developed by Hoffman (1985). Their six-stage categories were modified by the authors of this paper and were used to describe the transformation of students' identities from sexist to anti-sexist.
\end{abstract}

\section{Keywords}

Identity Transformation, Gender, Hoffman Stages of Identity, Patriarchy, Sexism, Anti-Sexist, Transformative Pedagogy

\section{Introduction}

American society was founded on patriarchy, a social system in which males held primary power and predominated in roles of political leadership, moral authority, social privilege and control of property. This society in the late $18^{\text {th }}$ century had laws that legitimized the favoring of males with property rights disputes, divorce as only possible with male consent, and no suffrage for women. Though these laws have changed and now ostensibly stress and enforce equality, informal relationships in families, peer groups, and co-workers perpetuate inequality (Davidson, Payne, Maltz, \& Rabow, 2015; Golshirazian, Dhillon, Maltz, Payne, \& Rabow, 2015; Payne \& Rabow, 2015). This paper examines whether the gender beliefs of female and male college students in an upper division college 
class in a public university can be modified and transformed into different and more inclusive higher stages of gender identity. We assess the attitudes and behavior of women and men towards their own and the other gender at three different time periods during the semester.

\section{The Class}

In the spring of 2016, 110 students (70 women and 40 men) were enrolled in an upper division sociology class entitled Ethnic Diversity in America (Sociology 307) at a major public university. The class was designed to introduce students to the inequalities perpetuated within American society with emphasis between ethnic relationships. Teaching pedagogy was guided by the belief that transformation between groups might occur when students would become aware of their identities and examine how these identities might support or challenge dominant social structures. If beliefs, attitudes, and behaviors associated with these identities could be discussed openly in a relatively safe environment, and environment that students felt free to express all their feelings and concerns, then the possibility of transformation would occur. A safe environment was provided to students in their weekly web posts, which were anonymous to the professor and instructors of the class. The class focused on the major identities of race, gender, and sexual orientation. In order to ensure that students would be involved in weekly discussions and also feel free to express their ideas, there were weekly assigned readings as well as required papers along with web posts. The pedagogy for the class was guided by the theoretical scheme of Transformative Pedagogy (Inspired by the pioneering work of Dewey (1986) and continuing with the contemporary scholarship of Hooks (1994) and Paulo Freire (1970)). Research on TP has developed to the point that we now have five models of transformative practices (Charbeneau, 2015; Cranton, 2002; Helms, 1990; Howard, 2006; Mezirow, 1997) as well as meta-analyses (Cranton, 2002; Taylor, 1997, 2001, 2007). The five models differ in the number of the stages described in the transformative process and the populations studied (Han, Philyaw, \& Rabow, 2015). The class was not taught with a conscious attempt to employ any one model but had developed efforts seeking to affect students' understandings of racism, sexism and homophobia (Dhillon, Moore, Rabow, \& Vega, 2013; Dhillon, Rabow, Han, Maltz, \& Moore, 2014; Rabow \& Dhillon, 2015; Rabow \& Yeghnazar, 2009). Building on the work of Helms' identity stages for whites, Hoffman was concerned with six identity stages for whites and people of color. We modified these stages to gender identities for women and men. The identities established by students are not fixed. People can move from one identity category to another, often changing their position based on whom they are with (Brubaker, 2016). However, our analysis argues that the classroom experiences helped transform identities.

We utilized the Hoffman identity stages as a framework to note the changes in students' attitudes about gender and sexism. The original framework was used to describe identity stages for people of color and whites. Originally, there were 6 
stages to classify identity for people of color and 6 stages to classify white identity. To change the model to fit sexism, the stages remained the same, but when the word "white" appeared, it was replaced with "men" and when "people of color" was used, we substituted the word "women." The resulting scheme had ten stages, as some stages applied to men and women, or exclusively to one gender.

The ten stages are briefly described below.

Hoffman Ten Identity Stages (modified for Sexism)

In the stage of conformity, women and men act in accordance with socially accepted standards.

In the stage of acceptance, men do not acknowledge sexism as an issue and any comments that indicate that sexism is alive are diminished or altogether rejected.

In the stage of dissonance, women begin to experience tension because while they are trying to move forward as "ordinary women," they begin to question sexism and its impact on their lives.

In the stage of immersion, women see sexism as a huge issue and the belief that most males are sexist angers them.

In the stage of resistance, men see sexism as a thing of the past and believe that the modern day sexism is actually against men.

In retreat, men begin to withdraw and move back as feelings of guilt arise after learning how sexism affects women and they begin to feel frustrated with other men and systems of power.

In the emersion stage, women avoid and fear men and feel more comfortable with other women.

In the stage of internalization, women begin to see that there are "good" men and that sexism is the enemy, not men.

In emergence, men begin to take control over the type of man they want to be after realizing their privilege and the ways that sexism has impacted and hurt women.

In the stage of integrative awareness, both women and men come to the realization that they are more than their gender and begin to appreciate their unique qualities while positively identifying with their gender.

\section{Sample}

There were a total of 110 students in the classroom, made up of 70 women and 40 men. This difference in the two group sizes can be handled by a chi square test, which is not affected by the difference in female to male ratio. We used the software from IBM SPSS for our analysis. Each student was required to post four times per week on the class website. The total possible number of posts was 7020. The actual number of posts was 4226 . This percentage (60\%) was due to absences as well as the failure of some students to do all 60 posts. As our analysis is upon gender we looked only at posts that specifically discussed gender. Of the 110 students, 63 wrote specifically about gender in 118 web posts. 32 out of the 
63 students wrote more than one web post. Twelve posts were written by students who openly identified as lesbian, gay or bisexual. Because of the pattern we noticed with these individuals, their posts were analyzed separately than the other 118 posts.

\section{Coding}

There were 118 posts on gender. Two independent coders were assigned to read through the web posts and assign a stage that the post embodied the most. These stages were taken from Hoffmans' identity stages. Of the 118 posts, 16 posts were disagreed upon by the two independent coders, but were only 1 stage apart. In those cases, we assigned a higher and then a lower stage to each disagreement. The two independent coders disagreed upon 8 posts that involved more than one stage of separation. A third independent coder analyzed these disagreements that were more than one stage apart and chose the stage that most accurately depicted the web post. A fourth coder analyzed the two case studies and decided a stage for each woman based on their overall reaction to the course material. With the 118 web posts and two case studies, there were 120 total student responses that were coded. In the final coding process, web posts were classified as pre-transformative or transformative. In the transformative stage for women (the final three stages of our identity model), there is a belief that sexism is the enemy and not men and there is a sense of self that goes beyond their gender identity. In the transformative stage for men (the final three stages of our identity model), there is occasional frustration with other men and systems of power; an understanding of how sexism has affected and hurt women and they begin to appreciate some qualities of their own gender. Finally, they understand that their sense of self goes beyond gender identity.

\section{Findings}

Four students who identified as LGBT had 11 out of 12 web posts that fell into a transformative stage. Fifty percent of these posts (6) were categorized in the last stage, integrative awareness, where both men and women are able to define themselves beyond their gender, and yet "positively identify" with their gender. A person in this stage is able to recognize and accept the other parts about their being beyond the characteristics that are identified with their gender. We believe this outcome is the result of what these students have experienced for the majority of their adolescence and young adulthood with not fitting neatly into the traditional categories of "woman" or "man” (Kimmel, 2004).

Table 1 indicates that the great majority of responses, from men and women, occurred immediately after the gender materials were introduced in the class $\left(\right.$ March $3^{\text {rd }}$ ). The number of responses lends some validity to the idea that students had been focusing on materials related to racism for the first five weeks (January $26^{\text {th }}$-March $1^{\text {st }}$ ). The frequency of their responses is reduced for both genders in the final five weeks (April $7^{\text {th }}$-May $10^{\text {th }}$ ). 
Table 1. Responses by men and women to gender issues in the 15-week course.

\begin{tabular}{ccccc}
\hline & $\begin{array}{c}\text { January } \\
26^{\text {th }} \text {-March } 1^{\text {st }}\end{array}$ & $\begin{array}{c}\text { March } 3^{\text {rd }} \text {-April } \\
6^{\text {th }}\end{array}$ & $\begin{array}{c}\text { April } 7^{\text {th }}-\text { May } \\
10^{\text {th }}\end{array}$ & $\begin{array}{c}\text { Total Number } \\
\text { of Responses }\end{array}$ \\
\hline Women & 1 & 57 & 22 & 80 \\
Men & 1 & 25 & 14 & 40 \\
$\begin{array}{c}\text { Total Number } \\
\text { of Responses }\end{array}$ & 2 & 82 & 34 & 120 \\
\hline
\end{tabular}

2 reveals that white women had no responses to the final and critical stage of Integrative Awareness, while women of color had two responses in that stage. Slightly less than half the responses from white women were in a transformative stage (6 out of 13). Less than half of responses ( 25 of $65,38 \%$ ) from women of color have achieved this identity development. A striking number of responses (7) from women of color are in the conformity stage. Overall, only 31 of the 80 responses (39\%) achieved an advanced identity position. This position includes an awareness that sexism is the enemy, that they can fight against it, and that they can begin to take control over their lives. When we convert Table 2 and examine the three pre-transformative stages and the final three transformative stages into a $2 \times 2$ table, we get the following results for Table 3 .

A chi-square test of significance reveals no significance difference between white women and women of color in their pre-transformative and transformative responses. Table 3 also indicates that women of color are less likely to engage in transformative responses (38\%) than white women who engage in transformative responses (46\%).

4 reveals that 34 of the 40 male responses were in the advanced three stages (transformative) of Hoffman's stages of identity. There is a sharp difference between the men of color and white men in their movement into transformative responses with $96 \%$ of the men of color and only $64 \%$ of the white men falling into the advanced transformative stage. However, none of the men achieved Integrative Awareness. When we convert Table 4 and examine the three pretransformative stages and the final three transformative stages into a $2 \times 2$ table, we get the following results for Table 5 .

A two-tailed chi-square test of significance found a moderate relationship (0.426) between the males and the stages of identity. A comparison of Tables 3-5 indicates that the men achieved an advanced stage of transformative statements (85\%) at a higher rate than the women (39\%).

\section{Discussion}

The effort to teach about the impact of sexism as a part of a class in ethnic relations achieved some success. Our findings, the transformation of gender identities in a classroom, have been duplicated in other studies (Weiler, 1988; Maher \& Tetreault, 2001; Banks \& Banks, 2009). Unlike these other studies, the transformation that we described here involves the process and stages of gender identity movement. This is an important dimension that has been neglected in other 
Table 2. Number of responses by women in Hoffmans' six stages of identity.

\begin{tabular}{cccccccc}
\hline & Conformity & Dissonance & Immersion & Emersion & Internalization & $\begin{array}{c}\text { Integrative } \\
\text { Awareness }\end{array}$ & $\begin{array}{c}\text { Total Number } \\
\text { of Responses }\end{array}$ \\
\hline $\begin{array}{c}\text { White Women } \\
(\mathrm{N}=5)\end{array}$ & 2 & 3 & 2 & 2 & 4 & 0 & 13 \\
$\begin{array}{c}\text { Women of Color } \\
(\mathrm{N}=38)\end{array}$ & 7 & 22 & 13 & 10 & 13 & 2 & 65 \\
$\begin{array}{c}\text { Total Number of } \\
\text { Responses }\end{array}$ & 9 & 25 & 15 & 12 & 17 & 2 & 80 \\
\hline
\end{tabular}

Table 3. Pre and transformative responses for white women and women of color.

\begin{tabular}{cccc}
\hline & PT & T & Total \\
\hline White Women $(\mathrm{N}=5)$ & 7 & 6 & 13 \\
Women of Color $(\mathrm{N}=38)$ & 42 & 25 & 65 \\
Total & 49 & 31 & 80 \\
\hline
\end{tabular}

Table 4. Number of responses by men in Hoffman's six stages of identity.

\begin{tabular}{cccccccc}
\hline & Conformity & Dissonance & Immersion & Emersion & Internalization & $\begin{array}{c}\text { Integrative } \\
\text { Awareness }\end{array}$ & $\begin{array}{c}\text { Total Number of } \\
\text { Responses }\end{array}$ \\
\hline $\begin{array}{c}\text { White Men } \\
(\mathrm{N}=7)\end{array}$ & 2 & 3 & 0 & 4 & 5 & 0 & 14 \\
$\begin{array}{c}\text { Men of Color } \\
(\mathrm{N}=15)\end{array}$ & 1 & 0 & 0 & 12 & 13 & 0 & 26 \\
$\begin{array}{c}\text { Total Number of } \\
\text { Responses }\end{array}$ & 3 & 3 & 0 & 16 & 18 & 0 & 40 \\
\hline
\end{tabular}

Table 5. Pre and transformative responses for white males and men of color.

\begin{tabular}{cccc}
\hline & PT & T & Total \\
\hline White Males & 5 & 9 & 14 \\
Males of Color & 1 & 25 & 26 \\
Total & 6 & 34 & 40 \\
\hline
\end{tabular}

research on gender transformation. The awareness of the role of sexism in the lives of students is demonstrated by the number of men and women in the class who responded to classroom experiences on their web posts identified with gender stages of development. The finding that men were more able to achieve transformative responses than women might be explained by the fact that privilege is easier to give up for males at this stage of their lives than women who have much more to lose by trusting men. Men who are under the age of 25 do not have to worry about job promotions, taking pay cuts, or affirmative action programs. The privileges they can give up have to do with inhibiting critical responses to women, name-calling and ridiculing. Women on the other hand at this age still have to concern themselves with cat-calls, safety and assault. The 
fact that a number of women in the class can trust the males in the class did not seem to generalize to other men.

\section{Conclusion}

The deficiencies in this research relates to our inability to ascertain how much change was actually made by each student, as we do not know where they were when starting the class. Because racism was the initial focus of the class, it is impossible for us to determine the relative influence, if any, of the readings and discussions about racism that may have affected the shifts in gender identity. Finally, because identities are continually in flux, we cannot fully determine whether the final stages achieved by students will be stable.

Despite these three limitations, there is significance that patriarchy in the various forms of gender oppression exists among college students in 2016. Even though, or perhaps because of the apparent progress in gender equality laws, contemporary university students still have oppressive beliefs and stereotypes about themselves and each other. The academic importance of our work is that a transformative pedagogy can modify gender identities. The most glaring challenge to a professor interested in transformative pedagogy about sexism is to provide opportunities for men to give up privileges related to power and for women to be able to increase their trust in men outside of the classroom. Making patriarchy a concept from the past is the challenge that lies ahead for individuals and institutions.

\section{References}

Banks, J. A., \& Banks, C. A. M. (2009). Multicultural Education: Issues and Perspectives. Hoboken, NJ: John Wiley \& Sons.

Brubaker, R. (2016). Trans: Gender and Race in an Age of Unsettled Identities. Princeton, NJ: Princeton UP. https://doi.org/10.1515/9781400883233

Charbeneau, J. (2015). White Faculty Transforming Whiteness in the Classroom through Pedagogical Practice. Race Ethnicity and Education, 18, 655-674. https://doi.org/10.1080/13613324.2013.831823

Cranton, P. (2002). Teaching for Transformation. New Directions for Adult and Continuing Education, 93, 63-72. https://doi.org/10.1002/ace.50

Davidson, C. R., Payne, K. E., Maltz, S., \& Rabow, J. (2015). The Cost and Effect of Gendering in the Family. Sociology Mind, 5, 227. https://doi.org/10.4236/sm.2015.54020

Dewey, J. (1986). Experience and Education. The Educational Forum, 50, 241-252. https://doi.org/10.1080/00131728609335764

Dhillon, M., Moore, J., Rabow, J., \& Vega, Y. M. (2013). First You Stand Out, Then You Stand Up: Becoming an Ally for the LGBT Community. Sociology Mind, 3, 333-338.

Rabow, J. (2013). Blasphemy into Alchemy: A Teaching Moment. Academic Exchange Quarterly Summer, 17,

Dhillon, M., Rabow, J., Han, V., Maltz, S., \& Moore, J. (2014). Achieving Consciousness and Transformation in the Classroom: Race, Gender, Sexual Orientations and Social Justice. Sociology Mind, 5, 74.

https://doi.org/10.4236/sm.2015.52008 
Golshirazian, S., Dhillon, M., Maltz, S., Payne, K. E, \& Rabow, J. (2015). The Effect of Peer Groups on Gender Identity and Expression. International Journal of Research in Humanities and Social Sciences, 2, 9-1781.

Han, V., Philyaw, Z., \& Rabow, J. (2015). Theorists of Transformation Pedagogy. International Journal of Humanities Social Sciences and Education, 2, 24-33.

Helms, J. (1990). Black and White Racial Identity: Theory, Research, and Practice. New York, NY: Greenwood Press.

Hoffman, J. J. (1985). Models of Racial Identity. http://www.academia.edu/4256205/Models_of_Racial_Identity

Hooks, B. (1994). Teaching to Transgress: Education as the Practice of Freedom. New York, NY: Routledge.

Howard, G. (2006). We Can't Teach What We Don't Know: White Teachers, Multiracial Schools (2nd ed.). New York, NY: Teachers College Press.

Kimmel, M. S. (2004). Masculinity as Homophobia: Fear, Shame, and Silence in the Construction of Gender Identity. In P. D. Rothenberg (Ed.), Race, Class, and Gender in the United States: An Integrated Study (pp. 81-93). New York, NY: Worth.

Maher, F. A., \& Tetreault, M. K. T. (2001). The Feminist Classroom: Dynamics of Gender, Race, and Privilege. Lanham, MD: Rowman \& Littlefield.

Mezirow, J. (1997). Transformative Learning: Theory to Practice. New Directions for Adult and Continuing Education, 74, 5-12. https://doi.org/10.1002/ace.7401

Payne, K. E., \& Rabow, J. (2015). The Hidden (and Not So Hidden) Curriculum of Schools: Structure, Biases and Stereotypes that Sculpt Gender. International Journal of Humanities Social Sciences and Education, 2, 55-64. www.arcjournals.org

Rabow, J., \& Yeghnazar, P. (2009). Transformative Teaching in the University: Uncovering and Confronting Racism, Sexism and Homophobia. Teaching Race and Ethnicityin Higher Education: Perspectives from North America. Birmingham: The Center for the Study of Sociology, Anthropology, and Politics-The Higher Education Academy Network, University of Birmingham.

Rabow, J., \& Dhillon, M. (2015). Balancing Scales of Language Injustice. Sociology Mind, 5, 23-26. https://doi.org/10.4236/sm.2015.51003

Taylor, E. (1997). Building upon the Theoretical Debate: A Critical Review of the Empirical Studies of Mezirow's Transformative Learning Theory. Adult Education Quarterly, 48, 34-59. https://doi.org/10.1177/074171369704800104

Taylor, E. (2001). Transformative Learning Theory: A Neurobiological Perspective of the Role of Emotions and Unconscious Ways of Knowing. International Journal of Lifelong Education, 20, 218-236. https://doi.org/10.1080/02601370110036064

Taylor, E. (2007). An Update of Transformative Learning Theory: A Critical Review of the Empirical Research (1999-2005). International Journal of Lifelong Education, 26, 173-191. https://doi.org/10.1080/02601370701219475

Weiler, K. (1988). Women Teaching for Change: Gender, Class \& Power. Santa Barbara, CA: Greenwood Publishing Group. 
Submit or recommend next manuscript to SCIRP and we will provide best service for you:

Accepting pre-submission inquiries through Email, Facebook, LinkedIn, Twitter, etc. A wide selection of journals (inclusive of 9 subjects, more than 200 journals)

Providing 24-hour high-quality service

User-friendly online submission system

Fair and swift peer-review system

Efficient typesetting and proofreading procedure

Display of the result of downloads and visits, as well as the number of cited articles Maximum dissemination of your research work

Submit your manuscript at: http://papersubmission.scirp.org/

Or contact sm@scirp.org 